\title{
Surface fire drives short-term changes in the vegetative phenology of woody species in a Brazilian savanna
}

\author{
Divino Vicente Silvério ${ }^{1,2,4}$, Oriales Rocha Pereira ${ }^{3}$, Henrique Augusto Mews ${ }^{3}$, \\ Leonardo Maracahipes-Santos ${ }^{2,3}$, Josias Oliveira dos Santos $^{3}$ \& Eddie Lenza ${ }^{3}$ \\ ${ }^{1}$ Universidade de Brasília, Departamento de Ecologia, Brasília, DF, Brazil. \\ ${ }^{2}$ Instituto de Pesquisa Ambiental da Amazônia, 66035-170, Belém, Pará, Brazil. \\ ${ }^{3}$ Universidade do Estado do Mato Grosso, Programa de Pós-graduação em Ecologia e Conservação, \\ Nova Xavantina, MT, Brazil. \\ ${ }^{4}$ Corresponding author: Divino Vicente Silvério, e-mail: dvsilverio@gmail.com
}

SILVÉRIO, D.V., PEREIRA, O.R., MEWS, H.A., MARACAHIPES-SANTOS, L., SANTOS, J.O., LENZA, E. Surface fire drives short-term changes in the vegetative phenology of woody species in a Brazilian savanna. Biota Neotropica. 15(3): e20140077. http://dx.doi.org/10.1590/1676-0611-BN-2014-0077

\begin{abstract}
We evaluated the effects of fire on the vegetative phenological behavior (crown foliage cover, sprouting, mature and young leaves) of woody species at two sites in the Brazilian savanna, one of which had been accidentally burned. We used generalized additive mixed models to test the hypothesis that: 1) fire damages total foliage cover, thus leading to changes in vegetative phenological patterns. As this hypothesis was corroborated, we also tested whether 2) the damage caused by fire to the total crown foliage cover and mature leaves is greater in evergreen than in deciduous species, and 3) the negative effects of fire on vegetative phenology persist after the first fire-free year. The first two hypotheses were corroborated, but the third was not. Fire effects on total crown foliage cover and mature leaves were greatest during the first three months following the fire, and were significantly greater in evergreen species. For shoots and young leaves, the greatest differences found between three and seven months post-fire. On the other hand, no differences were observed in phenological events between burned and unburned sites in the second year post-fire, indicating that marked effects of the fire were only observed over a short period. Our results showed immediate negative effects on the vegetative phenophases, but also that these effects are transient, and cannot be discerned after the first fire-free year.
\end{abstract}

Keywords: crown foliage cover, deciduity, fire ecology, phenology, sprouting.

SILVÉRIO, D.V., PEREIRA, O.R., MEWS, H.A., MARACAHIPES-SANTOS, L., SANTOS, J.O., LENZA, E. A passagem do fogo resulta em mudanças de curto prazo para a fenologia vegetativa de espécies lenhosas em um cerrado stricto sensu. Biota Neotropica. 15(3): e20140077. http://dx.doi.org/10.15 90/1676-0611-BN-2014-0077

Resumo: Avaliamos os efeitos do fogo sobre o comportamento fenológico vegetativo (cobertura de copa, brotação, folhas jovens e folhas adultas) de espécies lenhosas em dois sítios de cerrado sensu stricto: um queimado acidentalmente e outro não queimado. Usamos modelos aditivos mistos generalizados para testar a hipótese de que 1) o fogo danifica a cobertura de folhas das copas, o que resulta em alterações nos padrões fenológicos vegetativos das espécies; sendo isso verdadeiro, testamos se 2) os danos causados pelo fogo na cobertura de copa e nas folhas adultas são maiores em espécies sempre verdes do que em espécies decíduas e se 3) os efeitos negativos do fogo sobre a fenologia vegetativa persistem após um ano sem fogo. As duas primeiras hipóteses foram corroboradas, mas a terceira não. Os efeitos do fogo na cobertura de folhagem da copa e nas folhas adultas foram maiores após três meses da ocorrência do fogo e significativamente maiores para espécies sempre verdes. Para brotação e folhas jovens, as maiores diferenças foram entre três e sete meses após a queimada. Por outro lado, não foram percebidas diferenças entre os eventos fenológicos vegetativos dos sítios no segundo ano após a ocorrência do fogo, o que indica que os efeitos do fogo foram expressivos apenas por curto período. Os nossos resultados mostraram que o efeito do fogo sobre os eventos fenológicos vegetativos é negativo e mais intenso logo após a ocorrência da queimada, mas também que estes efeitos são temporários, e não são mais percebidos após o primeiro ano da ocorrência do fogo.

Palavras-chave: cobertura de copa, deciduidade, fogo, fenologia, rebrota. 


\section{Introduction}

Natural wildfires have occurred in the Brazilian Cerrado for thousands of years (Miranda et al. 2002, Miranda \& Sato 2004, Mistry et al. 2005), leading to many morphological, physiological and functional adaptations in the vegetation of this biome (Coutinho 1982, Hoffmann 1999). These adaptations include the marked suberization of trunks and branches (Hoffmann \& Moreira 2002), increased investment in reserves of carbohydrates and nutrients (Hoffmann \& Moreira 2002), and high sprouting capacity (Hoffmann 1999, Hoffmann \& Moreira 2002, Hoffmann \& Solbrig 2003). These adaptations appear to be effective against the damage caused by less severe, occasional natural wildfires (Medeiros \& Fiedler 2004, Miranda \& Sato 2004), but the increasing human occupation of the Cerrado region, which began in the early 1950 s, has altered the natural fire regime, increasing the frequency of fires, and altering seasonal patterns (Klink \& Machado 2005). A number of recent studies (Frost \& Robertson 1987, Moreira 2000, Miranda et al. 2002, Hoffmann et al. 2009) have indicated that the adaptations of Cerrado plants may be less effective in this modified scenario, given observed increases in mortality rates and modifications in recruitment patterns.

The available data indicate that fire damage has immediate effects on both vegetative and reproductive phenophases (Hoffmann 1998, Miranda et al. 2002). As the high temperatures of the flames causes abscission of the leaves, the foliage of woody species is damaged immediately (Miranda et al. 2002, Hoffmann \& Solbrig 2003). Negative effects are also seen in the number of flowers (Felfili et al. 1999) and fruits produced (Landim \& Hay 1996, Hoffmann 1998, Felfili et al. 1999). However, some species (mainly herbs and shrubs) may benefit from fire damage, which may actually intensify vegetative propagation (Hoffmann 1999, Hoffmann et al. 2009). Even though these studies have provided important insights into the vegetative and reproductive responses of woody savanna species to fire damage, little is known of the immediate effects of fire on deciduous and evergreen species, the persistence of these effects over time or their influence on the timing of vegetative phenological events in the woody plants of savanic physiognomies of the Brazilian Cerrado. In order to better understand the effects of fire on the vegetative phenological events of the woody species, we tested the following hypotheses: 1) given that the foliage of the tree crown can be destroyed by the flames or damaged by the flow of hot air (Miranda et al. 2009), there will be immediate damage to the leaf cover, leading to alterations in the pattern of vegetative phenological events during subsequent months; 2) considering that deciduous species lose all their leaves during the dry season (Lenza \& Klink 2006), the effects on the foliage and mature leaf cover will be greater in evergreen in comparison with deciduous ones; 3 ) the negative effects of fire damage on vegetative phenology persist after the first fire-free year.

\section{Material and Methods}

\section{Study area}

We conducted this study in an area of cerrado sensu stricto (the main savanna formation of the Brazilian Cerrado; see Oliveira-Filho \& Ratter 2002) in the Bacaba Municipal Park $\left(14^{\circ} 41^{\prime} \mathrm{S}, 52^{\circ} 20^{\prime} \mathrm{W}\right)$, a 492 ha protected area in Nova
Xavantina, a municipality in the Brazilian state of Mato Grosso. The regional climate is Aw according to Köppen's classification (Silva et al. 2008), with a mean annual temperature of $24^{\circ} \mathrm{C}$ and annual rainfall of approximately $1500 \mathrm{~mm}$ (INMET, 2012). The soils are deep, well drained, and acidic $(\mathrm{pH}<5)$, and have high levels of exchangeable Aluminum and low concentrations of Calcium and Magnesium (Marimon-Junior \& Haridasan 2005).

\section{Data collection}

We monitored the vegetative phenological events in the woody species found in two cerrado plots $100 \mathrm{~m}$ apart, representing: 1) burned and 2) unburned or control habitat. On May 2008, we marked 236 adult individuals representing 25 species in the burned plot (see Table S1 at http://dx.doi.org/ 10.6084/m9.figshare.1304520). On September 2008, this plot was burned accidentally. As no fires were recorded in the park during the preceding five years, a great deal of flammable material had accumulated, resulting in flames that attained a height of $5 \mathrm{~m}$, reaching the canopy (Mews et al. 2013). No precipitation had been recorded during the four months prior to the fire. On the day the fire occurred, the relative humidity of air was $41 \%$, the temperature of the air was $29^{\circ} \mathrm{C}$, with a maximum of $40^{\circ} \mathrm{C}$ and minimum of $17^{\circ} \mathrm{C}$, and mean wind speed was $2 \mathrm{~km} \mathrm{~h}^{-1}$ (INMET 2012). We marked 138 adult individuals in the unburned plot in September 2008 (a week after fire occurrence in September 9th), representing 13 of the woody species found in the burned plot (see Table S1 at http:// dx.doi.org/10.6084/m9.figshare.1304520). These 25 species accounted for $70 \%$ of the individuals and $62.5 \%$ importance value index (IVI) of the woody community of this site (Gomes et al., 2011). Species representing all four vegetative phenological groups (sensu Lenza \& Klink 2006) were present in both of our study plots (see Table S1 at http://dx.doi.org/10.6084/ $\mathrm{m} 9$.figshare.1304520). We sampled only individuals with no evidence of damage on trunk, and to ensure independence, individuals of the same species must be at least $10 \mathrm{~m}$ apart.

We recorded the vegetative phenological events every fortnight starting in May 2008 in the burned plot and in September 2008 in the unburned plot, with both plots being monitored simultaneously from September 2008 until September 2010. For each individual, we estimated: 1) total crown foliage cover (denominated crown foliage); 2) the proportion of the crown foliage composed of leaves with complete morphological and structural features (mature leaves); 3 ) the proportion of the crown foliage composed of recently formed leaves with expanded blades but without the morphological characteristics of mature leaves (young leaves); 4) initial bud development with initial leaf formation (shoots or sprouts). We visually estimated the phenophase intensity (PI) applying the method suggested by Fournier (1974). This is based on a semiquantitative interval scale of five categories ( 0 to 4$)$, where: $0=$ lack of the phenophase, $1=$ intensity of $1-25 \%, 2=26-50 \%$, $3=51-75 \%$, and $4=76-100 \%$.

\section{Numerical analysis}

We tested the hypotheses applying generalized additive mixed models, or GAMMs (Pinheiro \& Bates 2000, Wood 2006). The first two hypotheses were tested using the first year post-fire data (September 2008 to September 2009), considering 
Evergreen with Continuous Growth (ECG) and Evergreen with Seasonal Growth (ESG) species as evergreen and Deciduous (DEC) and Brevideciduous (BDC) species as deciduous (see Table S1 at http://dx.doi.org/10.6084/m9.figshare.1304520). In order to test the third hypothesis, we used the second year postfire data (September 2009 to September 2010). The GAMMs are suitable for phenology studies because they permit the analysis of non-linear responses and the identification of random factors, such as temporal autocorrelation, which are common in phenology studies (Wood 2006, Hudson et al. 2010, Polansky \& Robbins 2013, Rabasa et al. 2013).

We evaluated the relevance of differences between sites for each phenophase by selecting models based on Akaike's Information Criterion, or AIC (Burnham \& Anderson 2002). For each hypothesis and phenophase, we adjusted three distinct predefined models: (M1) This is the simplest model included only phenophase intensity (PI) as a function of time (in this case, the model evaluates the smooth function of the PI over time, representing seasonality - Table 1); (M2) In addition to evaluating the occurrence of seasonality, this model also verified difference in the PI between sites, but without taking possible interaction between factors into account. This is a semi-parametric model in which the difference between sites is calculated as a linear function (see Wood 2006 and Polansky \& Robbins 2013); and (M3) This is the most complex model, which considers PI as a function of time, and its potential interaction with the smooth function of the data for the two sites (Table 1). The AIC indicated that the data were best adjusted to a Poisson distribution (with square root link), and this distribution was used in all the models. We also included, in each model: (a) species as a random factor, and (b) temporal autocorrelation in the data (autocorrelation structure for a corCAR 1 continuous time interval: Pinheiro \& Bates 2000). We assessed the significance of random factors through the graphic adjustment of the residuals and the confidence intervals of the parameters, as well as correlograms. We conducted these analyses using the R package $m g c v$ (Wood 2006, R Core Team 2012).

We assessed the possibility that both sites presented similar vegetative phenological behavior prior to disturbance by applying Pearson's correlation coefficient, r (ZAR 1999) between the MODIS (MOD13A1) enhanced vegetation index (EVI) and our crown foliage cover data at the two sites (NASA 2012). We used the same correlation (r) to evaluate the relationship between crown foliage cover and the MODIS EVI time series, in order to evaluate the representativeness of the phenological events of the two study populations in relation to those of the community as a whole. The leaf area of cerrado sensu stricto is influenced by both tree and grass layer, but they have similar pattern throughout the year and is strongly correlated to remotely sensed vegetation indices, such as the EVI (Hoffmann et al 2005).

\section{Results}

In the unburned plot, a significant relationship (79\%) was found between crown foliage cover and the EVI values $(r=0.790, \mathrm{~N}=30, \mathrm{p}<0.05$; Figure 1), although this relationship was even stronger $(90 \%)$ in the burned plot $(r=0.902, \mathrm{~N}=46, \mathrm{p}<0.05 ;$ Figure 1$)$. The correlation between the pre-burned MODIS EVI of the two sites was $97 \%$ ( $r=0.975, \mathrm{~N}=16, \mathrm{p}<0.05$, Figure 1$)$, indicating that the vegetative phenology of the study species was representative of that of the woody community as a whole.

The fire resulted in significant modifications of all the vegetative phenophases (crown foliage, mature leaves, shoots, and young leaves) during the first year after the fire (September 2008 to September 2009). The model that included the differences between plots and the interaction with the smooth function (M3) provided the best adjustment for the data on crown foliage, mature leaves, and sprouting events (Table 2). However, M2, which also included the differences between plots, was the best model for the data on young leaves (Table 2). The parameters of the best models were significant for all phenophases (see Table S2 at http://dx.doi.org/10.6084/ $\mathrm{m} 9$. figshare.1304639) and thus corroborated our first hypothesis. The results indicated a delay of almost two months in the recovery of the crown foliage, more intense leaf production during the six months following the fire, and, finally, early leaf production during the subsequent sprouting season in the burned plot in comparison with the unburned one (Figure 2).

The intensity of the crown foliage was still low in the burned plot during the subsequent five months, although the two plots were characterized by similar levels of intensity during the rest of the first year following the fire (Figure 2a). We also verified an absolute reduction in mature leaf cover in the burned plot, which remained close to zero for approximately one month after the fire, although the crown foliage then recovered rapidly (Figure 2c). Mature leaf cover was already above $75 \%$ three months following burning, with similar levels of intensity being recorded at both sites from this moment onwards, until the end of the first year post-fire. The fire damage also modified the intensity of the production of young leaves and shoots. Between three and seven months after the fire, these phenophases were more intense in the burned plot in comparison with the unburned one. In the unburned plot, the intensity of sprouting and young leaves reached similar levels only by the mid-rainy season, that is, December (Figures 2b, d).

Table 1. Summary of the basic parameterized generalized additive mixed models for each vegetative phenophase of the woody species studied in Nova Xavantina, Mato Grosso, Brazil. PI = Phenophase intensity; data = time series; SI = site; $\mathrm{s}=$ smooth function; $\mathrm{b}=$ beta.

\begin{tabular}{|c|c|c|}
\hline Model & Equation & Description \\
\hline Model 1 (M1) & $\mathrm{PI} \sim \mathrm{s}($ data $)$ & Seasonality of phenophase intensity (PI) \\
\hline Model 2 (M2) & $\mathrm{PI} \sim \mathrm{s}($ data $)+\mathrm{b}(\mathrm{SI})$ & $\begin{array}{l}\text { Seasonality of the PI at the different sites (SI), where the difference between } \\
\text { sites is calculated by adding a beta value (with no possibility of interaction). }\end{array}$ \\
\hline Model 3 (M3) & $\mathrm{PI} \sim \mathrm{s}($ data $)+\mathrm{s}(\mathrm{SI})$ & $\begin{array}{l}\text { Seasonality of the PI for the different sites estimated by calculating independent } \\
\text { smooth functions for each factor. }\end{array}$ \\
\hline
\end{tabular}




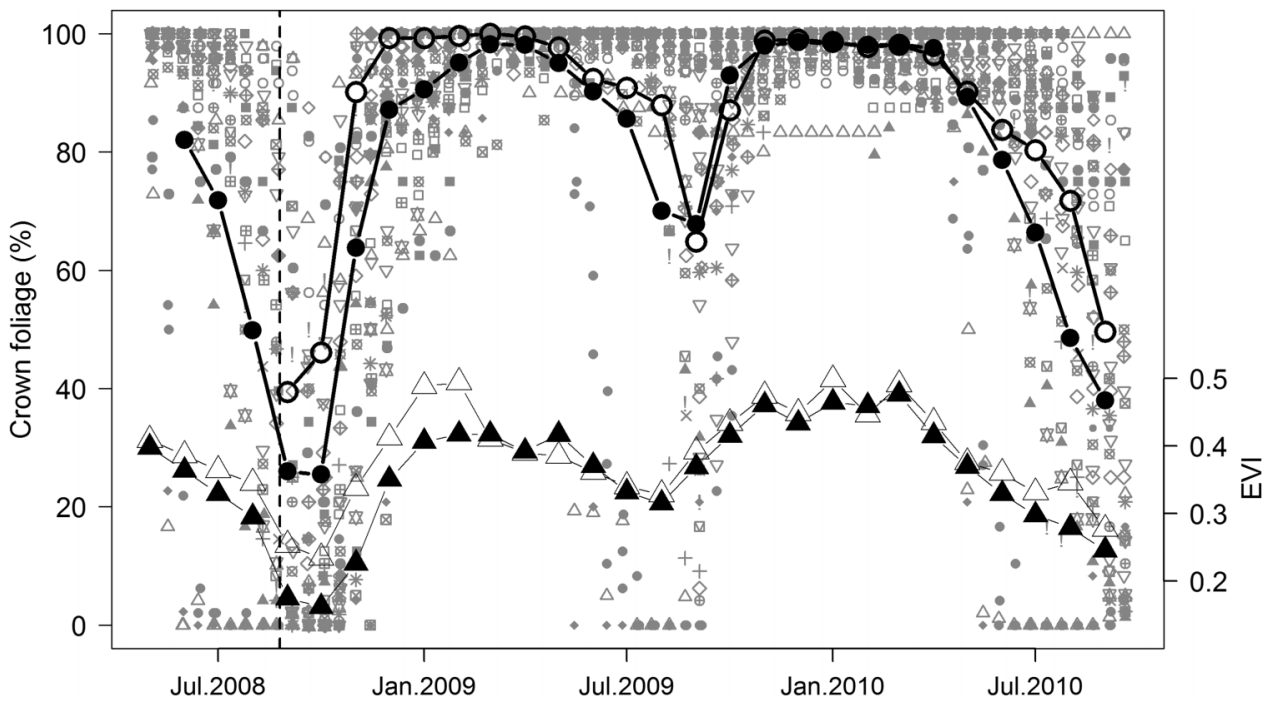

Figure 1. Crown foliage cover in the burned $(\bullet)$ and unburned $(O)$ plots and MODIS enhanced vegetation index (EVI) for the burned $(\mathbf{\Delta})$ and unburned $(\triangle)$ plots in an area of Cerrado savanna area in Nova Xavantina, Mato Grosso, Brazil. Different symbol represent distinct species. The dotted line indicates when the fire occurred.

The fire had a greater effect on the evergreen species in comparison with the deciduous ones, in relation to both the crown foliage and mature leaf cover. In the case of the evergreen species, the models that included the differences between sites provided the best fit for the data (Table 2), with significant parameters (see Table S2 at http://dx.doi.org/ $10.6084 / \mathrm{m} 9$.figshare.1304639). However, the inclusion of the difference between sites did not result in any improvement in the adjustment of the models for the deciduous species (Table 2). These results fully support the second hypothesis. The crown foliage cover of evergreen species decreased sharply in the burned plot, whereas in the unburned plot, there was no significant reduction in the intensity of these phenophases, even at the end of the dry season (Figure 4). Even so, the phenophase intensity (for crown foliage and mature leaves) of the deciduous species in the unburned plot was reduced by less than $20 \%$ following the fire, indicating that the vegetative events of these species were less affected by fire (Figure 4).

During the second year following the fire, the inclusion of the differences between sites did not result in any improvement of the adjustment of the models for any of the vegetative phenophases (Table 2). These results are inconsistent with the third hypothesis, i.e., that the negative effects of the fire on vegetative phenophases will persist after the first year following the fire (Figure 3, Table 2), but rather provide evidence of the capacity of the woody species of the cerrado to recover their

Table 2. Model selection parameters for four vegetative phenophases in burned and unburned plots in an area of Cerrado savanna in Nova Xavantina, Mato Grosso, Brazil, for the first (2008-2009) and second (2009-2010) years following a wildfire. The Akaike Information Criterion (AIC) in bold type indicates the best-fit model for the given parameter. $\mathrm{df}=$ degrees of freedom; Loglik $=$ logarithm of the likelihood ratio.

\begin{tabular}{|c|c|c|c|c|c|c|c|c|c|}
\hline & \multirow[t]{2}{*}{ df } & \multicolumn{2}{|c|}{ Year 1} & \multicolumn{2}{|c|}{ Year 2} & \multicolumn{2}{|c|}{ Evergreen } & \multicolumn{2}{|c|}{ Deciduous } \\
\hline & & AIC & $\overline{\text { Loglik }}$ & AIC & Loglik & AIC & Loglik & AIC & Loglik \\
\hline \multicolumn{10}{|c|}{ Crown foliage } \\
\hline M1 & 6 & -22.37 & 17.18 & -394.56 & 203.28 & -162.50 & 87.25 & 36.95 & -13.47 \\
\hline M2 & 7 & -29.71 & 21.86 & -389.89 & 201.94 & -159.78 & 86.89 & 39.37 & -13.68 \\
\hline M3 & 9 & -34.95 & 26.48 & -34.95 & 26.47 & -169.35 & 93.67 & 107.87 & -47.93 \\
\hline \multicolumn{10}{|c|}{ Shoots } \\
\hline M1 & 6 & 321.19 & -154.60 & 157.91 & -72.95 & & & & \\
\hline M2 & 7 & 333.75 & -159.88 & 427.18 & -206.59 & & & & \\
\hline M3 & 9 & 319.11 & -150.55 & 164.26 & -73.12 & & & & \\
\hline \multicolumn{10}{|c|}{ Mature leaves } \\
\hline M1 & 6 & 58.98 & -23.49 & -197.98 & 104.98 & -50.67 & 31.33 & -14.89 & 12.44 \\
\hline M2 & 7 & 8.35 & 2.82 & -196.52 & 105.25 & -30.86 & 22.43 & -13.08 & 12.54 \\
\hline M3 & 9 & -54.78 & 36.39 & -190.80 & 104.39 & -85.42 & 51.71 & 18.75 & -1.37 \\
\hline \multicolumn{10}{|c|}{ Young leaves } \\
\hline M1 & 6 & 264.49 & -126.24 & 98.93 & -43.46 & & & & \\
\hline M2 & 7 & 236.57 & -111.28 & 111.91 & -48.95 & & & & \\
\hline M3 & 9 & 348.95 & -165.48 & 115.27 & -48.63 & & & & \\
\hline
\end{tabular}




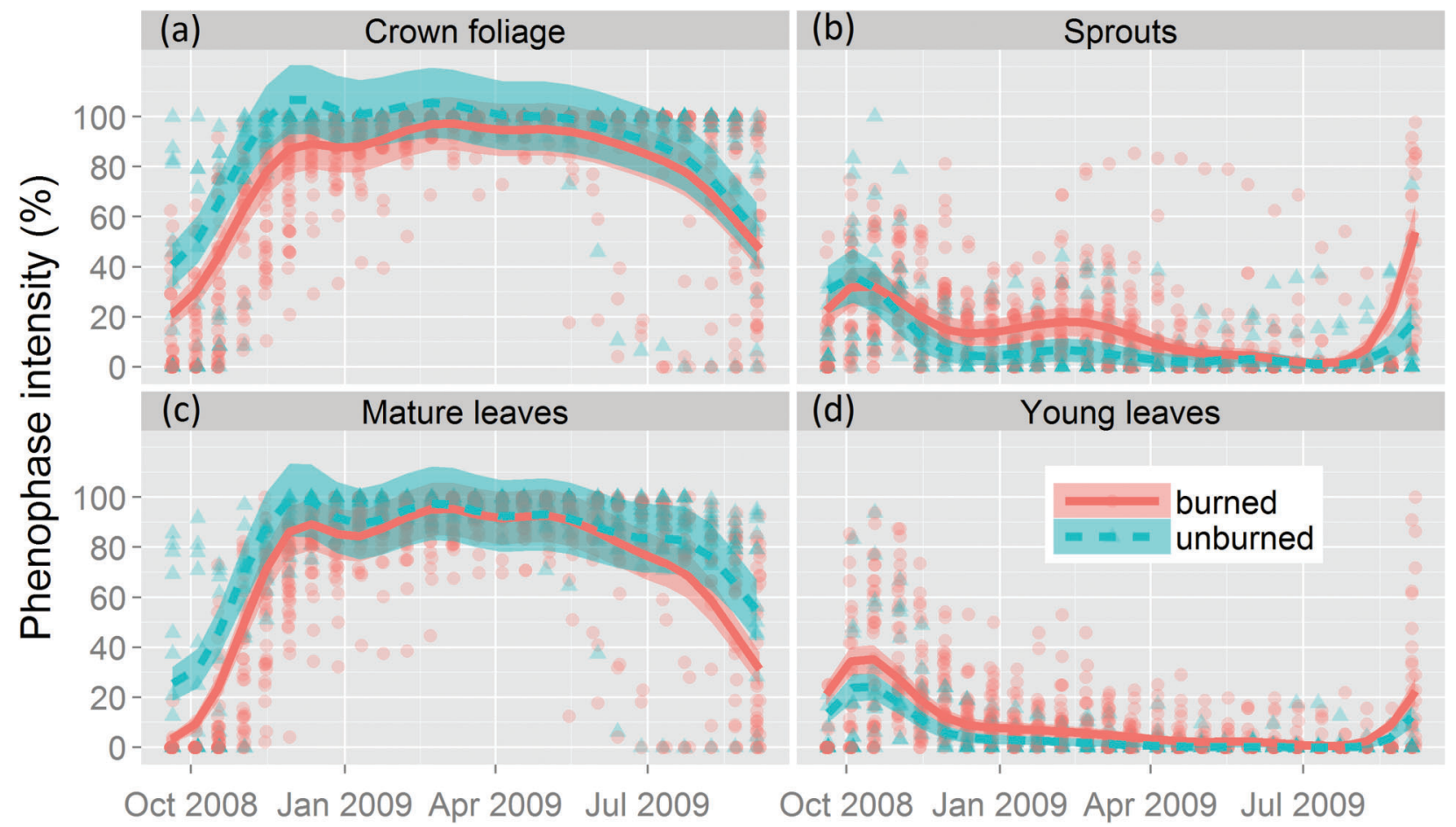

Figure 2. Phenological behavior predicted by the best model (M3, see material and methods) for the four vegetative phenophases of the woody species monitored in burned and unburned plots of Cerrado savanna in Nova Xavantina, Mato Grosso, Brazil. The points indicate the mean phenophase intensity of each species in the burned $(\mathbf{\Delta})$ and unburned $(\bullet)$ plots. Shaded areas represent the confidence intervals $($ alpha $=0.05)$.

vegetative phenology patterns. In the case of mature leaves, there was little difference in the AIC values for models M1 and M2 (difference = 1.46; Table 2). In spite of this, the fixed parameter of difference between plots in M2 was not significant $(t=-1.5 ; p=0.132)$. This result reinforces the idea that the effects of fire on the vegetative monitoring in the present study cannot be detected once the vegetation has recovered for a year.

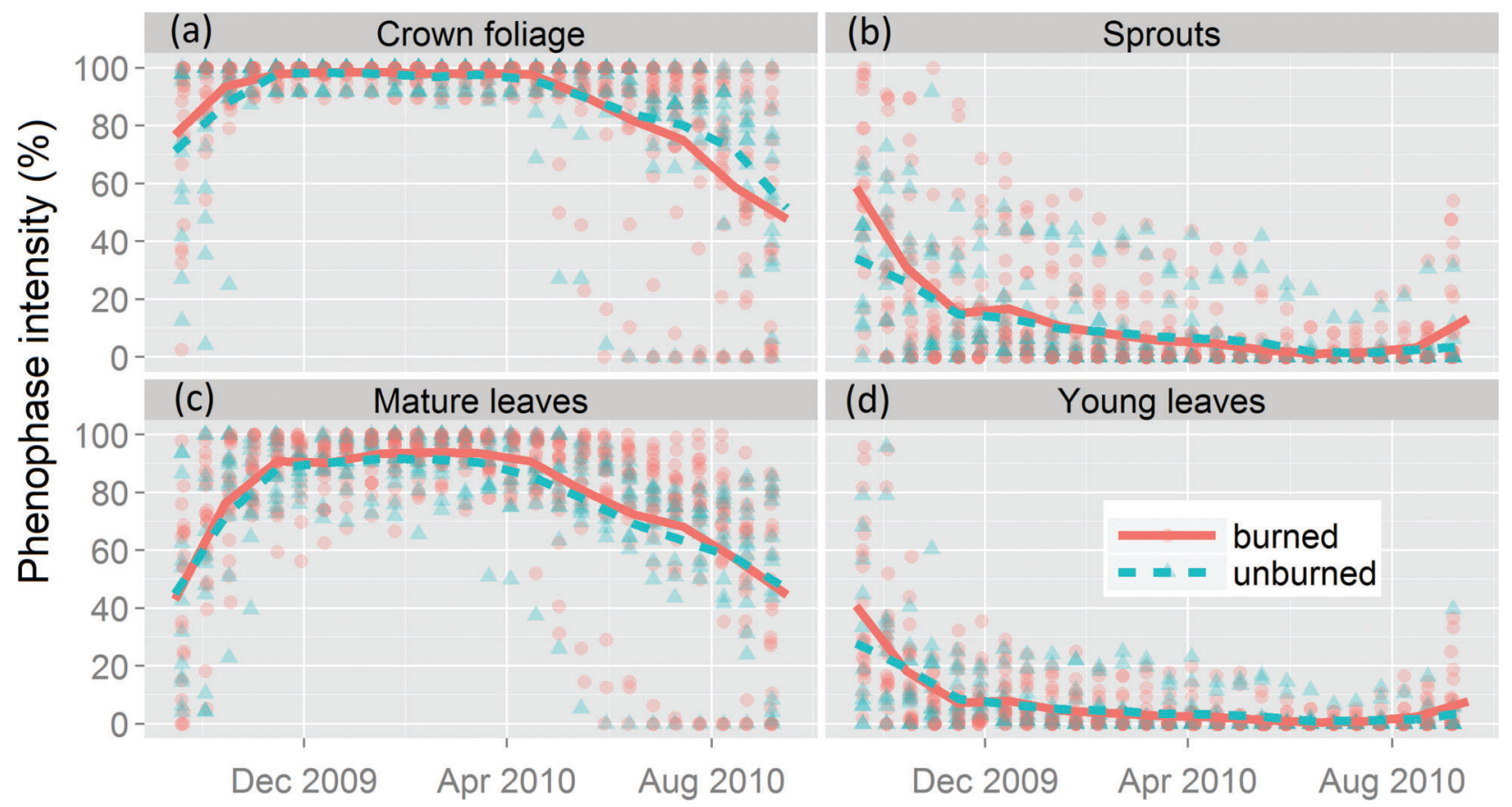

Figure 3. Phenological behavior predicted by the best model (M3, see material and methods) for the four vegetative phenophases of the woody species monitored in burned and unburned plots of Cerrado savanna in Nova Xavantina, Mato Grosso, Brazil. The lines represent the arithmetic mean of the phenophase intensity, and the points indicate the mean phenophase intensity for each species monitored in the burned ( $\mathbf{\Delta})$ and unburned $(\diamond)$ plots. 


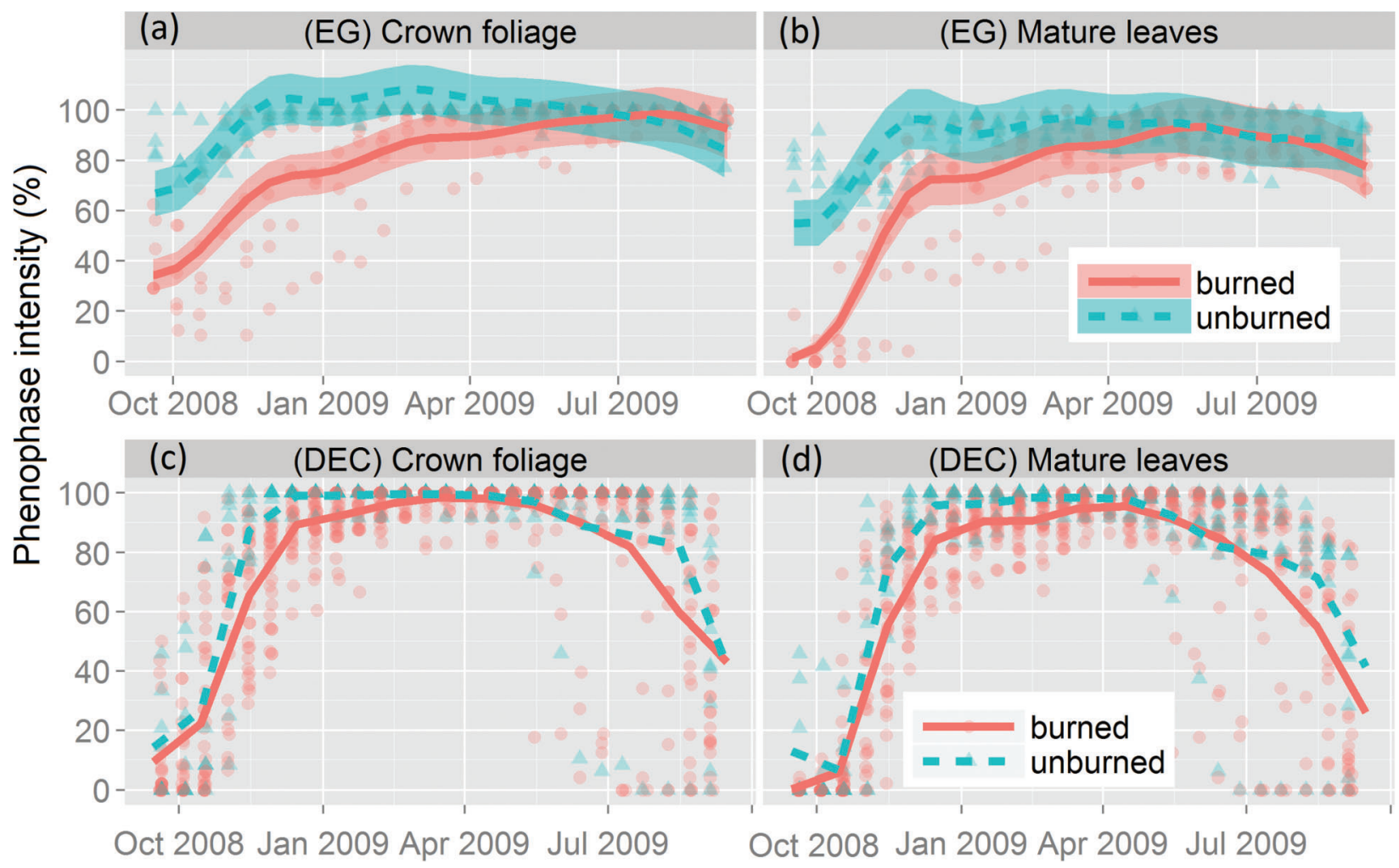

Figure 4. Vegetative phenological behavior of the crown foliage and mature leaves predicted by the best model for the evergreen species (EG) and arithmetic mean of the phenophase intensity for deciduous species (DEC) monitored in the burned and unburned plots of Cerrado savanna in Nova Xavantina, Mato Grosso, Brazil. The points indicate the mean phenophase intensity of each species monitored in the burned $(\boldsymbol{\Delta})$ and unburned $(\bullet)$ plots. Shaded areas represent the confidence intervals (alpha $=0.05$ ).

\section{Discussion}

The significant fire damage caused in the crown foliage, shoots and young leaves indicates an immediate response of the vegetative phenophases of woody species. Woody species of the cerrado are known to concentrate the production of new leaves at the end of the dry season (August and September) (Felfili et al. 1999, Lenza \& Klink 2006, Oliveira 2008). This typical pattern was recorded in both sites, but burned plot presented high levels of sprouting during rainy season also. The intense production of shoots and young leaves reflected the response of the individuals to burning and the recovery of the foliage. The more intense production of leaves in the burned plot nearly one year after burning may represent an additional phase in the recovery of the foliage. These results indicate that woody species of cerrado are not only characterized by the sprouting capacity of their subterraneous organs (Hoffmann 1998, Moreira, 2000, Miranda et al. 2002), but also their epigeous recovery mechanisms for fire damage, such as a capacity for intense sprouting during a period of up to 12 months following a fire.

The deciduity and sprouting capacity of woody cerrado species are interpreted as evolutionary adaptations to frequent fire events (Oliveira 2008). Even though deciduous (DEC) or brevideciduous (BDC) species lose all their leaves at the end of dry season (Lenza \& Klink 2006), we observed that fire may have significant negative effects on the vegetative phenophases of the community as a whole. The pre-burned crown foliage intensity of the DEC and BDC species was lower than $20 \%$. These species accounted for $64 \%$ of the study species (see Table S1 at http://dx.doi.org/10.6084/m9.figshare.1304520), which may account for the community's reduced crown foliage cover when the fire occurred (Figure 1 and 2a). The high correlation between the EVI and the crown foliage intensity in the unburned plot indicates that the study species are representative of the local woody vegetation, and support our prediction of negative effects on the vegetative phenophases of the community as a whole. Similarly, the high correlation between the pre-burned EVI of both sites is evidence of the similar phenological behavior of the undisturbed vegetation, and provides support for the conclusion that the differences observed between the study plots are primarily a consequence of the fire event. However, soil fertility and soil water content are also important factors associated to the three productivity and vegetation structure (de Assis et al. 2011, Oliveira-Filho \& Ratter 2002). Results of a early study show that soil fertility tend to be similar in our study area even if vegetation structure is different (Marimon-Junior \& Haridasan 2005) and possible variation in soil water content should be reduced given that studied sites are flat and adjacent.

Analyzing the phenological groups (evergreen vs. deciduous) separately, the immediate fire damage to the crown foliage cover was due primarily to the loss of foliage in the evergreen species with continuous and seasonal growth, which still presented high crown foliage cover (68\%), even at the end of the dry season. In their analysis of adjacent habitats that had been either subject to frequent fires over a 20 year period, or protected from these events, Moreira et al. (2000) found that eight of the 10 study species strongly related to the fireprotected environments were evergreen, whereas the two tree species that were strongly related to the frequent-fire habitats 
(Bowdichia virgilioides and Piptocarpha rotundifolia) were deciduous (Lenza \& Klink 2006). Woody species of the cerrado usually have deep roots, enabling them to reach water even during the dry season (Scholz et al. 2002, Franco et al. 2005), and crown foliage recovery preceding the rainy season (Lenza \& Klink 2006, Oliveira 2008). In this case, the natural occurrence of fires over the past million years (Vicentini 1993, Miranda et al. 2009) may have gradually eliminated evergreen species in favor of deciduous ones. In this scenario, the ongoing increase in the frequency of fires in the Brazilian cerrado resulting from the increase in human activities occurring over the past few decades (Miranda et al. 2009) may result in a further reduction in the relative importance of evergreen species, through the reduction or extinction of local populations, resulting in an increase in the seasonality of savanic physiognomies of the Brazilian Cerrado and further changes in litter production and nutrient cycling.

Although the immediate damage to vegetative phenophases, the effects of the fire did not persist for long. Physical and chemical changes in the environment resulting from the passage of the fire appear to favor the recovery of the vegetative phenophases of trees that are still alive. The rapid recovery of the crown foliage, and the increase in sprouting intensity and the production of young leaves may all have benefited from the reduction in competition for space and light resulting from the loss of foliage (Miranda et al. 2002, Hoffmann \& Solbrig 2003). In addition, fire enhances mineralization and availability of nutrients (i.e., $\mathrm{Ca}, \mathrm{K}, \mathrm{Mg}$, and $\mathrm{N}$ ) in the superficial layers of the soil (Coutinho 1982, Mistry 1998), enabling the rapid recovery of leaf production. In fact, a number of studies have recorded a post-fire increase in the nutrient concentrations of the leaves of woody species (Batmanian \& Haridasan 1985, Nardoto et al. 2006), indicating that the phenological behavior of the plants following a fire may be related to alterations in environmental conditions and the availability of nutrients.

Our results confirm the prediction that fire causes immediate negative effects on the vegetative phenophases of the woody cerrado species (Hoffmann 1998, Felfili et al. 1999, Fernandes-Bulhão \& Figueiredo 2002). However, these effects were short-lived, due to the marked and rapid increase in sprouting and the production of leaves following the fire. This suggests compensatory behavior in the vegetative phenophases in response to burning. The woody stratum may respond positively to the addition of nutrients, increasing in biomass, litter production, and shading (Haridasan 2008), so the shortterm effects of fire on the phenology of surviving individuals and the increase in the nutrient concentrations of the leaves (Nardoto et al. 2006) may reflect the more efficient uptake of the nutrients made available by the fire (Coutinho 1982, Mistry 1998). The deep roots of the woody species and their capacity to redistribute the humidity available in the soil even during the dry season (Scholz et al. 2002) further support this conclusion. However, it is important to note that the recent increase in the frequency of burning, compared to the natural occurrence of wildfires, may have significant negative effects on the vegetation of the cerrado. The long-term benefits of more open savanna habitats, differential mortality of the woody species with low fire tolerance, and the reduction in the nutrient pool due to runoff and discharge into the atmosphere, may all be important factors in this process (Moreira 2000, Miranda et al. 2002, Roitman et al. 2007).
The results presented here show that fire has immediate negative effects on the vegetative phenophases of the woody plants of the Brazilian savanna, and that these effects are greater in evergreen species in comparison with deciduous ones. However, the rapid recovery of the crown foliage through the increased production of shoots and young leaves meant that the negative effects persisted for a short period of time. These characteristics combine to enhance the capacity of the woody species, and the community as a whole, to recover from wildfires. Despite this, the human occupation of the Brazilian Cerrado over the past few decades has changed the natural fire regime, and further studies will be required in order to evaluate the capacity of evergreen and deciduous plants to respond to consecutive fires or events occurring at different times of the year. Among other things, this will allow us to understand whether the increased investment of resources in leaf production will influence future reproductive events and the overall dynamics of the woody community.

\section{Acknowledgments}

We thank the Higher Education Training Program (CAPES) of the Brazilian government for granting scholarships to D.V. Silvério, O.R. Pereira, H.A. Mews, L. MaracahipesSantos and J.O. dos Santos. This paper is part of the first author's thesis in the Graduate Program in Ecology and Conservation, Mato Grosso State University (UNEMAT) in Brazil.

\section{References}

BATMANIAN, G.J. \& HARIDASAN, M. 1985. Primary production and accumulation of nutrients by the ground layer community of cerrado vegetation of central Brazil. Plant and Soil 88(3): 437-440, http://dx.doi.org/10.1007/BF02197500

BURNHAM, K.P. \& ANDERSON, D.R. 2002. Model Selection and Multimodel Inference: A Practical Information-Theoretic Approach. Springer-Verlag, New York.

CARVALHO-JÚNIOR, O.A., SAMPAIO, C.S., SILVA, N.C., COUTO-JÚNIOR, A.F., GOMES, R.A.T., CARVALHO, A.P.F. \& SHIMABUKURO, Y.E. 2008. Classificação de padrões de savana usando assinaturas temporais NDVI do sensor MODLS no Parque Nacional Chapada dos Veadeiros. Rev. Bras. Geof. 26(4): 505-517, http://dx.doi.org/10.1590/S0102-261X2008000400010

COUTINHO, L.M. 1982. Ecological effects of fire in Brazilian Cerrado. In Ecology of tropical savannas (B.J. Huntley \& B.H. Walker, eds). Springer, Berlin, p.273-290, http://dx.doi.org/ 10.1007/978-3-642-68786-0

de Assis, A.C.C, Coelho, R.M., da Silva Pinheiro, E, Durigan, G., 2011. Water availability determines physiognomic gradient in an area of low-fertility soils under Cerrado vegetation. Plant Ecol. 212: 1135-1147, http://dx.doi.org/10.1007/s11258-010-9893-8

FELFILI, J.M., SILVA-JUNIOR, M.C., DIAS, B.J. \& REZENDE, A.V. 1999. Estudo fenológico de Stryphnodendron adstringens (Mart.) Coville no cerrado sensu stricto da Fazenda Água Limpa no Distrito Federal, Brasil. Rev. Brasil. Bot. 22(1): 83-90, http://dx.doi.org/10.1590/S0100-84041999000100011

FERNANDES-BULHÃO, C. \& FIGUEIREDO, P.S. 2002. Fenologia de leguminosas arbóreas em uma área de cerrado marginal no nordeste do Maranhão. Rev. Brasil. Bot. 25(3): 361-369, http://dx. doi.org/10.1590/S0100-84042002000300012

FOURNIER, L.A. 1974.Un método cuantitativo para la medición de características fenológicas en árboles. Turrialba 24(4):422-423.

FRANCO, A.C., BUSTAMANTE, M., CALDAS, L.S., GOLDSTEIN, G., MEINZER, F.C., KOZOVITS, A.R, RUNDEL, P. \& 
CORADIN, V.T.R. 2005. Leaf functional traits of Neotropical savanna trees in relation to seasonal water deficit. Trees 19(3): 326-335, http://dx.doi.org/10.1007/s00468-004-0394-z

FROST, P.G.H. \& ROBERTSON F. 1987. The ecological effects of fire in savannas. In Determinants of Tropical Savannas (B.J. Walker, ed.) IUBS Special, Paris, p. 93-140.

GOMES, L., LENZA, E., MARACAHIPES, L., MARIMON, B.S. \& OLIVEIRA, E.A. 2011. Comparações florísticas e estruturais entre duas comunidades lenhosas de cerrado típico e cerrado rupestre, Mato Grosso, Brasil. Acta bot. bras. 25(4): 865-875, http://dx.doi. org/10.1590/S0102-33062011000400013

HARIDASAN, M. 2008. Nutritional adaptations of native plants of the cerrado biome in acid soils. Brazilian J. Plant Physiol. 20(3): 183-195, http://dx.doi.org/10.1590/S1677-04202008000300003

HOFFMANN, W.A. \& MOREIRA, A.G. 2002. The Role of Fire in Population Dynamics of Woody Plants. In The Cerrados of Brazil: ecology and natural history of a neotropical savanna (R.S. Oliveira \& P.S. Marquis, eds). The University of Columbia Press, New York, p. $159-177$.

HOFFMANN, W.A. \& SOLBRIG, O.T.2003. The role of topkill in the differential response of savanna woody species to fire. For. Ecol. Manag. 180(1-3): 273-286, http://dx.doi.org/10.1016/S0378-1127 (02)00566-2

HOFFMANN, W.A, SILVA Jr, E.R, MACHADO, G.C, BUCCI, S.J, SCHOLZ, F.G, GOLDSTEIN, G, MEINZER, F.C. 2005. Seasonal leaf dynamics across a tree density gradient in a Brazilian savanna. Oecologia 145: 307-316, http://dx.doi.org/10.1007/ s00442-005-0129-x

HOFFMANN, W.A., ADASME, R., HARIDASAN, M., CARVALHO, M.T., GEIGER, E.L., PEREIRA, M.A., GOTSCH, S. \& FRANCO, A.C. 2009. Tree topkill, not mortality, governs the dynamics of savanna-forest boundaries under frequent fire in central Brazil. Ecology 90(5): 1326-1337, http://dx.doi.org/10.1890/ 08-0741.1

HOFFMANN, W.A. 1998. Post-burn reproduction of woody plants in a neotropical savanna: the relative importance of sexual and vegetative reproduction. J. Appl. Ecol. 35(3): 422-433, http://dx. doi.org/10.1046/j.1365-2664.1998.00321.x

HOFFMANN, W.A. 1999. Fire and population dynamics of woody plants in a neotropical savanna: matrix model projections. Ecology 80(4): 1354-1369, http://dx.doi.org/10.1890/0012-9658(1999)080 [1354:FAPDOW]2.0.CO;2

HUDSON, I.L., KIM, S.W. \& KEATLEY, M.R. 2010. Climatic Influences on the Flowering Phenology of Four Eucalypts: A GAMLSS Approach. In Phenological Research - Methods for Environmental and Climate Change Analysis. (I.L. Hudson \& M.R. Keatley, eds). Springer: Netherlands, p. 209-228.

INMET. 2012. Monitoramento das Estações Convencionais. Instituto Nacional de Meteorologia, http://www.inmet.gov.br/html/rede_obs. php (last access in 12/12/2012).

KLINK, C.A. \& MACHADO, R.B. 2005. Conservation of the Brazilian Cerrado. Conserv. Biol 19(3): 707-713, http://dx.doi.org/ 10.1111/j.1523-1739.2005.00702.x

LANDIM, M. \& HAY, J. 1996. Impacto do Fogo sobre alguns aspectos da biologia reprodutiva de Kielmeyera coriacea Mart. Rev. Brasil. Biol. 56(1): 127-134.

LENZA, E \& KLINK, C.A. 2006. Comportamento fenológico de espécies lenhosas em um cerrado sentido restrito de Brasília, DF. Rev. Brasil. Bot. 29(4): 627-638, http://dx.doi.org/10.1590/S010084042006000400013

MARIMON-JUNIOR, B.H. \& HARIDASAN, M. 2005. Comparação da vegetação arbórea e características edáficas de um cerradão e um cerrado sensu stricto em áreas adjacentes sobre solo distrófico no leste de Mato Grosso, Brasil. Acta bot. bras. 19(4): 913-926, http://dx.doi.org/10.1590/S0102-33062005000400026

MEDEIROS, M.B. \& FIEDLER, N.C. 2004. Incêndios florestais no Parque Nacional da Serra da Canastra: desafios para a conservação da biodiversidade. Ciên. Florest. 14(2): 157-168.
MEWS H.A., SILVÉRIO D.V., LENZA E. \& MARIMON B.S. 2013. Influência de agrupamentos de bambu na dinâmica pós-fogo da vegetação lenhosa de um cerrado típico, Mato Grosso, Brasil. Rodriguésia 64(2): 211-221, http://dx.doi.org/10.1590/S217578602013000200002

MIRANDA, H.S. \& SATO, M.N. 2004. Efeitos do fogo na vegetação lenhosa do Cerrado. In Cerrado: Ecologia e Caracterização (L.M.S. Aguiar \& A.J.A Camargo, eds). Embrapa Cerrados: Planaltina, p. 66-123.

MIRANDA, H.S., SATO, M.N., NETO, W.N. \& AIRES, F.S. 2009. Fires in the cerrado, the Brazilian savanna, in: Cochrane, M.A. (Ed.), Tropical Fire Ecology. Springer Berlin Heidelberg, Berlin, Heidelberg, pp. 427-450.

MIRANDA, H.S., BUSTAMANTE, M.M.C. \& MIRANDA, A.C. 2002. The Fire Factor. In The Cerrados of Brazil: Ecology and Natural History of a Neotropical Savanna (R.S. Oliveira \& P.S. Marquis, eds.). The University of Columbia Press: New York, p. 51-68.

MISTRY, J., BERARDI, A., ANDRADE, V., KRAHÔ, T., KRAHÔ, P. \& LEONARDOS, O. 2005. Indigenous Fire Management in the cerrado of Brazil: The Case of the Krahô of Tocantíns. Hum. Ecol. 33(3): 365-386, http://dx.doi.org/10.1007/s10745-005-4143-8

MISTRY, J. 1998. Fire in the cerrado (savannas) of Brazil: an ecological review. Prog. Phys. Geogr. 22(4): 425-448, http://dx.doi.org/ 10.1177/030913339802200401

MOREIRA, A.G. 2000. Effects of fire protection on savanna structure in Central Brazil. J. Biog. 27(4): 1021-1029, http://dx.doi.org/ 10.1046/j.1365-2699.2000.00422.x

NARDOTO, G.B., BUSTAMANTE, M.M.C., PINTO, A.S. \& KLINK, C.A. 2006. Nutrient use efficiency at ecosystem and species level in savanna areas of Central Brazil and impacts of fire. J. Trop. Ecol. 22(2): 191-201, http://dx.doi.org/10.1017/ S0266467405002865

NASA. 2012. The Moderate Resolution Imaging Spectroradiometer (MODIS), http://modis.gsfc.nasa.gov/ (last access in 12/12/2013).

OLIVEIRA-FILHO, A.T. \& RATTER, J.A. 2002. Vegetation Physiognomies and Woody Flora of the Cerrado Biome. In The Cerrados of Brazil: ecology and natural history of a neotropical savanna (P.S. Oliveira \& R.J. Marquis, eds.). Columbia University Press: New York, p.91-120.

OLIVEIRA, P.E. 2008. Fenologia e biologia reprodutiva das espécies de Cerrado. In Cerrado: ecologia e flora (S.M. Sano, S.P. Almeida. \& J.F. Ribeiro, eds.). Embrapa Cerrados: Planaltina, p.169-188.

PINHEIRO, J.C. \& BATES, D.M. 2000. Mixed Effects Models in $\mathrm{S}$ and S-Plus. Springer, Berlin.

POLANSKY, L. \& ROBBINS, M.M. 2013. Generalized additive mixed models for disentangling long-term trends, local anomalies, and seasonality in fruit tree phenology. Ecol. Evol. 3(9): 3141-3151, http://dx.doi.org/10.1002/ece3.707

R CORE TEAM. 2012. R: A language and environment for statistical computing. Vienna: R Foundation for Statistical Computing, http://www.R-project.org (last access in 12/12/2013).

RABASA, S.G., GRANDA, E., BENAVIDES, R., KUNSTLER, G., ESPELTA, J.M., OGAYA, R., PEÑUELAS, J., SCHERERLORENZEN, M., GIL, W., GRODZKI, W., AMBROZY, S., BERGH, J., HÓDAR, J.A., ZAMORA, R. \& VALLADARES, F. 2013. Disparity in elevational shifts of European trees in response to recent climate warming. Glob. Chang. Biol. 19(8): 2490-2499, http://dx.doi.org/10.1111/gcb.12220

ROITMAN, I., FELFILI, J.M. \& REZENDE, A.V. 2007. Tree dynamics of a fire-protected cerrado sensu stricto surrounded by forest plantations, over a 13-year period (1991-2004) in Bahia, Brazil. Plant Ecol. 197(2): 255-267, http://dx.doi.org/10.1007/ s11258-007-9375-9

SCHOLZ, F.G., BUCCI, S.J., GOLDSTEIN, G., MAINZER, F.C. \& FRANCO, A.C. 2002. Hydraulic redistribution of soil water by neotropical savanna trees. Tree Physiol. 22(9): 603-612, http://dx. doi.org/10.1093/treephys/22.9.603 
SILVA, F.A.M., ASSAD, E.D. \& EVANGELISTA, B.A. 2008. Caracterização climática do Bioma Cerrado. In Cerrado: ecologia e flora (S.M. Sano, S.P. Almeida \& J.F. Ribeiro, eds). Embrapa Cerrados, Planaltina, p.69-88.

SILVÉRIO, D.V. \& LENZA, E. 2010. Fenologia de espécies lenhosas em um cerrado típico no Parque Municipal do Bacaba, Nova
Xavantina, Mato Grosso, Brasil. Biota Neotrop. 10(3): 205-216, http://dx.doi.org/10.1590/S1676-06032010000300024

WOOD, S.N. 2006. Generalized Additive Models: an introduction with R. Chapman and Hall/CRC, Florida.

ZAR, J.H. 1999. Biostatistical Analysis. 4th ed. Prentice Hall, New Jersey.

Received 25/06/2014

Revised 30/07/2015

Accepted 18/08/2015 